\title{
Micro-players for macro-roles: aquatic microbes in deep lakes
}

\author{
Cristiana CALLIERI \\ CNR - Institute of Ecosystem Study, Largo Tonolli 50, 28922 Verbania Pallanza, Italy \\ Corresponding author: c.callieri@ise.cnr.it
}

\begin{abstract}
Despite their relative low volume on a global scale, lakes represent a valuable reserve of accessible freshwaters. Any increase in our understanding of their functioning is a step towards their better exploitation and preservation. Microorganisms drive the metabolic processes that regulate the biogeochemical cycles in lakes; here, I will focus on Archaea and Cyanobacteria as micro-players playing macro-roles in lake ecosystems. In particular, I will present two examples to demonstrate the importance of prokaryotes in lakes: picocyanobacteria and mesophilic archaea. The role of prokaryotes in lakes will be discussed in relation to their taxonomy, dynamics and ecology using these two examples. The challenge, now, is to better understand the relationship between the diversity and the physiology of various ecotypes, how these interact with each other and with environmental factors allowing the proliferation of the most competitive genotypes.
\end{abstract}

Key words: Aquatic microbes; Synechococcus; Thaumarchaeota; lakes.

Received: April 2015. Accepted: May 2015.

\section{PICOCYANOBACTERIA}

The main components of autotrophic picoplankton in lakes are Synechococcus-type cyanobacteria, which generally exceeds the eukaryotic fraction. For this reason, autotrophic picoplankton is often considered as synonymous of picocyanobacteria. We know that the percentage of eukaryotic cells in the pico-size range increases in eutrophic or distrophic systems (Callieri, 2007) and in humic lakes (Jasser and Arvola, 2003). The ecological characteristics of picocyanobacteria and picoeukaryotes are different; however, their role in the trophic chain, as a carbon reserve for grazers, is similar due to their commensurate size-range.

Here I will report results from studies referred mainly to picocyanobacteria in deep lakes, where they play a significant role as primary producers (Callieri and Piscia, 2002). Two main genera, Synechococcus and Cyanobium, dominate in freshwaters. Synechococcus can be present in lakes both as single-cell and as microcolony (Passoni and Callieri, 2000; Callieri at al., 2012) (Fig. 1). Microcolony formation can be facilitated by the presence of a regularly ordered globular protein (S-layer) on the cell surface (Ernst et al., 1996), or even by rigid spinae, induced by grazers (Jezberová and Komárková, 2007). Another effective factor on microcolony formation is the ultraviolet radiation (UVR; 280-400 nm). It has been demonstrated that a selected Synechococcus ribotype, acclimated to low light, formed microcolonies as a quickdefence strategy (Callieri et al., 2011). These monoclonal microcolonies, similar to those found in nature, should not be mistaken for aggregates like the ones that form after exposition to high blue light, as a result of the production of oxygen reactive radicals (Kobližek et al., 2000). It has been suggested that microcolonies may be considered transition forms from single-cells to true colonial, changing the trophic role of Synechococcus in the food web (Callieri et al., 2012). Microcolonies are generally present throughout the euphotic zone, with a peak of abundance in summer or autumn in a variety of lakes (Passoni and Callieri, 2000; Komárková, 2002; Crosbie et al., 2003b; Mózes et al., 2006; Ivanikova et al., 2007). In general, single cells tend to prefer large, deep oligomesotrophic lakes, whereas microcolonies dominate in warm, shallow eutrophic lakes.

It is important to recall that Synechococcus are gramnegative bacteria with an outer membrane of lipopolysaccharide (LPS), and a peptidoglycan layer considerably thicker than that of most gram-negative bacteria (Hoiczyk and Hansel, 2000). They also have surface porins with a strict molecular size cutoff that potentially protect them from harmful agents (Hoiczyk and Hansel, 2000). As a consequence, due to their characteristics they are small sized autotrophic cells able to compete with larger phytoplankton in harsh conditions. An example of the different ecological niches occupied by picocyanobacteria and by the larger autotrophic fraction is clearly evident in North Patagonian ultraoligotrophic lakes (Fig. 2) (Modenutti et al., 2004; Callieri et al., 2007). In such extreme environments, picocyanobacteria are successful as they do not compete with phytoplankton, but rather take up the most unfavourable zone in the water column. This stratification takes place thanks to the small size of picocyanobacteria and to the phycobiliprotein content in the cell, which 
makes the increase of photosynthetic efficiency at low light possible (Callieri et al., 2007).

Picocyanobacteria importance increases with their numbers relative to total phytoplankton in oligotrophic lakes, even if their abundances are higher in eutrophic lakes (Stockner et al., 2000). The model proposed (Stockner et al., 2000) was after enlarged by using data from 38 lakes, including high altitude clear lakes, deep large subalpine and ultraoligotrophic andine lakes, large shallow lakes, small reservoirs and fish ponds (Callieri et al., 2007) (Fig. 3). In terms of activity, picophytoplankton contribution to total primary production increases in oligotrophic waters reaching up to $80 \%$ (Lake Baikal; Nagata et al., 1994). During the process of Lake Maggiore oligotrophication a trend towards the increase of the percentage of picophytoplankton production on the total primary production was observed (Fig. 4); nevertheless, their numbers from 1992 to 2013 showed a pronounced decreasing trend (Fig. 5).

In eleven oligotrophic lakes of western Canada the relative contribution of picophytoplankton to total photosynthesis ranged from 29 to 53\% (Stockner and Shortreed, 1991, 1994). A wider fluctuation has been found in Lake Constance, where the ${ }^{14} \mathrm{C}$ incorporation varied between 0.1 and $7.5 \mathrm{mg} \mathrm{C} \mathrm{m}^{-3} \mathrm{~h}^{-1}$ with a relative contribution of 5-65\% of total phytoplankton production. By examining the vertical profile of carbon uptake in Lake Maggiore, the percentage contributions of pico on total phytoplankton varied from year to year (ranging up to 40-80\%) (Stockner et al., 2000). In 2002, in Lake Maggiore the daily production was $13-266 \mathrm{mg} \mathrm{C} \mathrm{m}^{-2} \mathrm{~d}^{-1}$ comprising up to $47 \%$ of total phytoplankton uptake (Fig. 6). Interestingly, the peaks of production were observed in the metalimnion at $25-10 \%$ of surface photosynthetic active radiation (PAR), even with only $1 \%$ of PAR on August, confirming the preference of picocyanobacteria for low light conditions (Fig. 7).

Light is known to be an important factor in niche differentiation for picocyanobacteria. Synechococcus ecotypes exhibit differences in their accessory pigments that affect their adaptation to spectral light quality (Haverkamp et al., 2009). The pigment composition of picocyanobacteria has been associated with a particular underwater light quality (McMurter et al., 1994). The influence of this factor on the selection of picocyanobacterial types with different pigment content has been studied in many lakes, covering a wide spectrum of trophic states and underwater light quality. In highly colored lakes, non-phycoerythrin cells (PC) dominated numerically, whereas in oligotrophic hard-water lakes phycoerythrin-rich cells (PE) were the most abundant (Pick, 1991; Vörös et al., 1998). The growth response of PE and PC Synechococcus cells demonstrated the selective value of red light in stimulating the PC and in suppressing PE (Callieri, 1996). Conversely, blue and green lights are used more efficiently than red wavelengths of similar intensity by Synechococcus PE-cells (Glover et al., 1985). In the field, $\mathrm{PC}$ are the majority when the red wavelength dominate, conversely PE exceed the PC when the green wavelength prevail (Fig. 8). The seasonal dynamics of Synechococcus population and subpopulations were demonstrated in Lake Constance (Becker et al., 2002) and Lake Maggiore (Callieri, 2007). The rapid diversification of Synechococcus at different depths in lakes and in the Baltic Sea has been demonstrated in studies on the $c p c \mathrm{BA}$ operon sequences (Crosbie et al., 2003a; Haverkamp et al., 2009).

The phylogenetic studies on 16S rRNA gene of Synechococcus published to date have revealed the existence
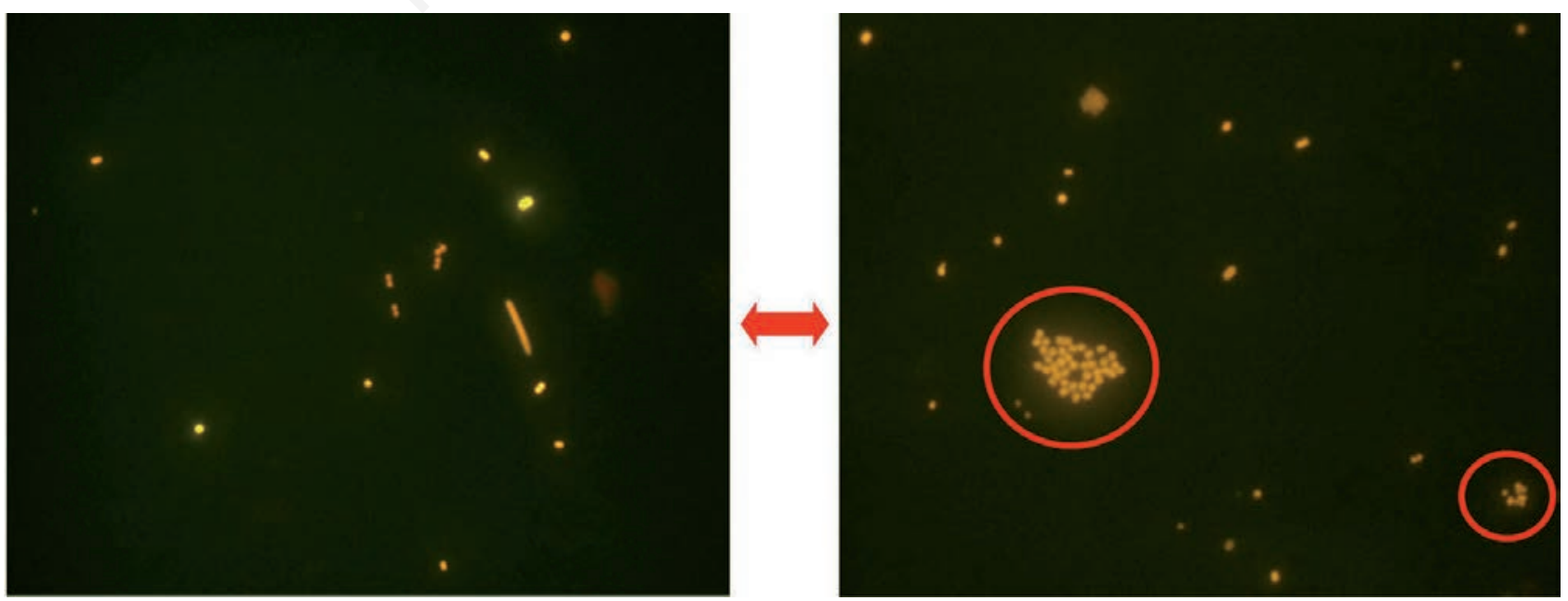

Fig. 1. Different morphotypes of picocyanobacteria (left panel) and microcolonies of different size (right panel) from Lake Maggiore. 
of three marine sub-clusters: 5.1, 5.2 and 5.3 (Scanlan et al., 2009), and around 13 clusters of non-marine picocyanobacteria (Callieri et al., 2013) (Fig. 9). Even if the majority of marine Synechococcus of open oceans belongs to sub-cluster 5.1, the less studied 5.2 and 5.3 appears to be very important to understand the phylogenetic evolution of Synechococcus and Cyanobium genera, as they have unexpected relations with the non-marine strains. The euryhaline PE-rich Cyanobium, isolated from the Arabian Sea, the Synechococcus 5.2 clade (Everroad and Wood, 2012) as well as the 5.3 clade, shared common ancestry with freshwater subalpine cluster II, with Lake
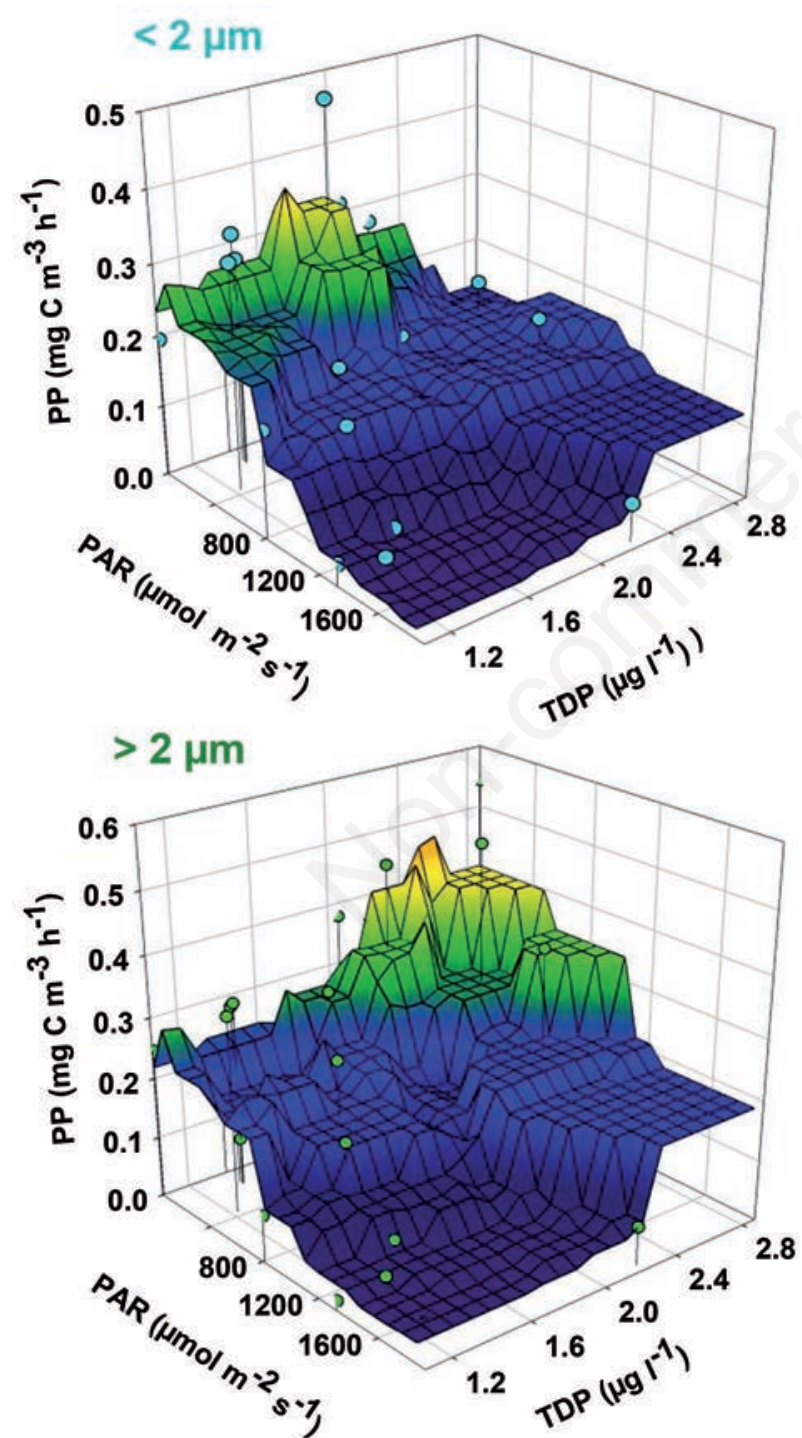

Fig. 2. Primary production of picophytoplankton $(<2 \mu \mathrm{m}$, upper panel) and $>2 \mu \mathrm{m}$ fraction (lower panel) in relation with total dissolved phosphorus and irradiance. Dots represent the experimental points. From: Callieri et al., 2007.
Nahuel Huapi cluster and Halotolerant cluster (Athalassohaline crater-lakes) (Callieri et al., 2013). The latter study, based on 16S rRNA, indicated new clades of halotolerants, shedding new light on the global distribution and evolution of picocyanobacteria.

\section{THAUMARCHAEOTA}

As a second example of microorganisms playing an important role in aquatic environments, I selected the mesophilic Archaea. In freshwaters, the presence of mesophilic Crenarchaeota (renamed Thaumarchaeota, Brochier-Armanet et al., 2008) has been ascertained in the deep oxygenated hypolimnion of Crater Lake (589 m) (Urbach et al., 2001), of Lake Maggiore (372 m) (Callieri et al., 2009) and in the moderately deep (73 m) high altitude Lake Redon (Auguet et al., 2012). Thaumarchaeota have also been found in the epilimnion and upper hypolimnion ( $\sim 50 \mathrm{~m})$ of other large lakes (Keough et al., 2003).

Phylogenetically, Thaumarchaeota clearly separate from Euryarchaeota and comprise Marine Group I (MGI) commonly found in oceanic and freshwater plankton (formerly 1.1a), and in Soil Group (formerly 1.1b) (Pester et al., 2011). The clade SAGMGC-1, sister to MG 1.1a, has been recently documented to be present at higher numbers in surface and lower at depth, in the high altitude Lake Redon (Auguet et al., 2012).

The laboratory experiments by Könneke et al. (2005) showed Thaumarchaeota to oxidize ammonia to nitrite; in this process, they have the ability to chemolithotrophically fix inorganic carbon (Herndl et al., 2005; Yakimov et al., 2011).

Research efforts have focussed, on one hand, on quan-

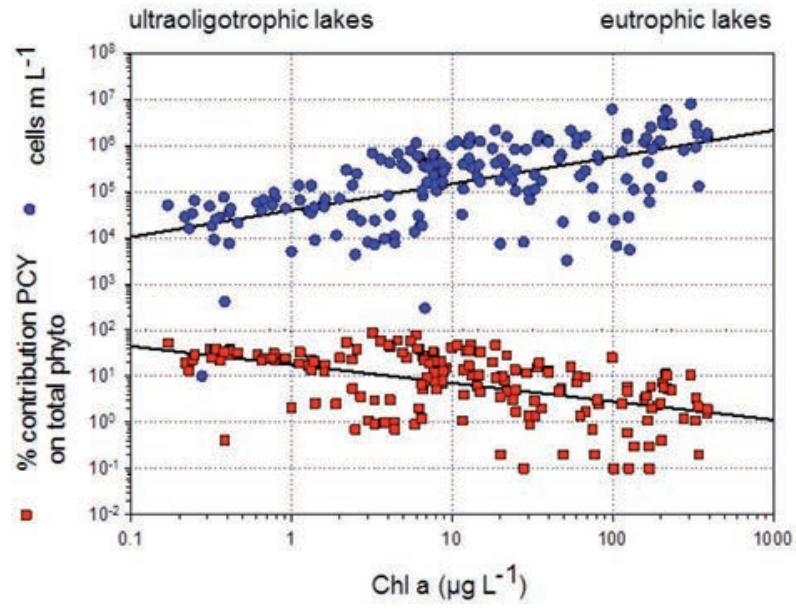

Fig. 3. Relationship between total autotrophic biomass ( $\mu \mathrm{g} \mathrm{Chl}$ $a \mathrm{~L}^{-1}$ ) and picophytoplankton abundance, and its percent contribution to total autotrophic biomass. Modified from Callieri et al., 2007. 
tifying the genes that codify for archaeal ammonia monooxygenase $(a m o \mathrm{~A})$, the first enzyme in the process of ammonia oxidation; and, on the other hand, on measuring the dark $\mathrm{CO}_{2}$ fixation. Moreover, the discovery of the assimilation path used by autotrophic Thaumarchaeota, the 3-hydroxypropionate/4-hydroxybutyrate cycle (Berg et al., 2007), has provided a molecular marker ( $\operatorname{ccc} \mathrm{C}$ ) to trace the Thaumarchaeota autotrophic activity (Auguet et al., 2008). In the bathypelagic Mediterranean Sea the archaeal amoA gene abundance was lower than Thaumarchaeota abundance (De Corte et al., 2009), indicating that these microorganism can perform other activities. Although a substantial fraction of Thaumarchaeota is chemoautotrophic, it has been found that they can contribute to heterotrophic activity. Using microautoradiography, it has been found that the MCGI group can contribute 32\% to leucine incorporation, throughout the water column in the eastern Atlantic (Yokokawa et al., 2012).

The in situ measurement of the dark $\mathrm{CO}_{2}$ assimilation of Thaumarchaeota and Bacteria in the aphotic water column of Lake Maggiore (Northern Italy) was $65.8 \pm 5.2 \mathrm{mg}$ $\mathrm{C} \mathrm{m}^{-2} \mathrm{~d}^{-1}$. This $\mathrm{CO}_{2}$ sink in the hypolimnion, due to dark uptake, represented $87 \%$ of the total picoplanktonic primary $\mathrm{CO}_{2}$ fixation taking place in the euphotic zone (Callieri et al., 2014). Therefore the $\mathrm{CO}_{2}$ uptake taking place in the hypolimnion is not negligible and constitutes a potentially significant $\mathrm{CO}_{2}$ sink. These estimates were obtained using a new custom-made apparatus, which takes samples and adds tracers in situ. The new instrument was used at different depths and conditions, and compared with parallel conventional on board incubations. In situ dark $\mathrm{CO}_{2}$ incorporations had lower standard deviation respect to the on board ones (Fig. 10).

In 2010, a study on the vertical distribution of Thaumarchaeota and Bacteria was performed on five subalpine lakes (Tab. 1) using CARD-FISH (see methods in Callieri et al., 2009). The percentages of Thaumarchaeota (probe Cren537) of total DAPI counts increased with depth in all lakes, with values around zero in the upper 40 meters, whereas the percentage of Bacteria (probe EUB I-III) showed an opposite trend (Fig. 11). Highest relative abundances of Thaumarchaeota were recorded in Lake Como (19\% of DAPI signals at $200 \mathrm{~m}$ depth), followed by Lakes

Tab. 1. Main morphometric characteristics of five subalpine lakes.

\begin{tabular}{lccccc} 
& Como & Zurich & Garda & Maggiore & Thun \\
\hline Latitude N & $46^{\circ} 00^{\prime}$ & $47^{\circ} 15^{\prime}$ & $45^{\circ} 42^{\prime}$ & $45^{\circ} 58^{\prime}$ & $46^{\circ} 41^{\prime}$ \\
Longitude E & $9^{\circ} 15^{\prime}$ & $8^{\circ} 41^{\prime}$ & $10^{\circ} 43^{\prime}$ & $8^{\circ} 39^{\prime}$ & $7^{\circ} 43^{\prime}$ \\
\hline Altitude (m asl) & 198 & 406 & 65 & 193 & 558 \\
Area $\left(\mathrm{km}^{2}\right)$ & 146 & 88 & 368 & 213 & 48 \\
\hline Maximum depth (m) & 410 & 136 & 350 & 370 & 217 \\
Mean depth (m) & 154 & 49 & 133 & 178 & 136 \\
\hline
\end{tabular}

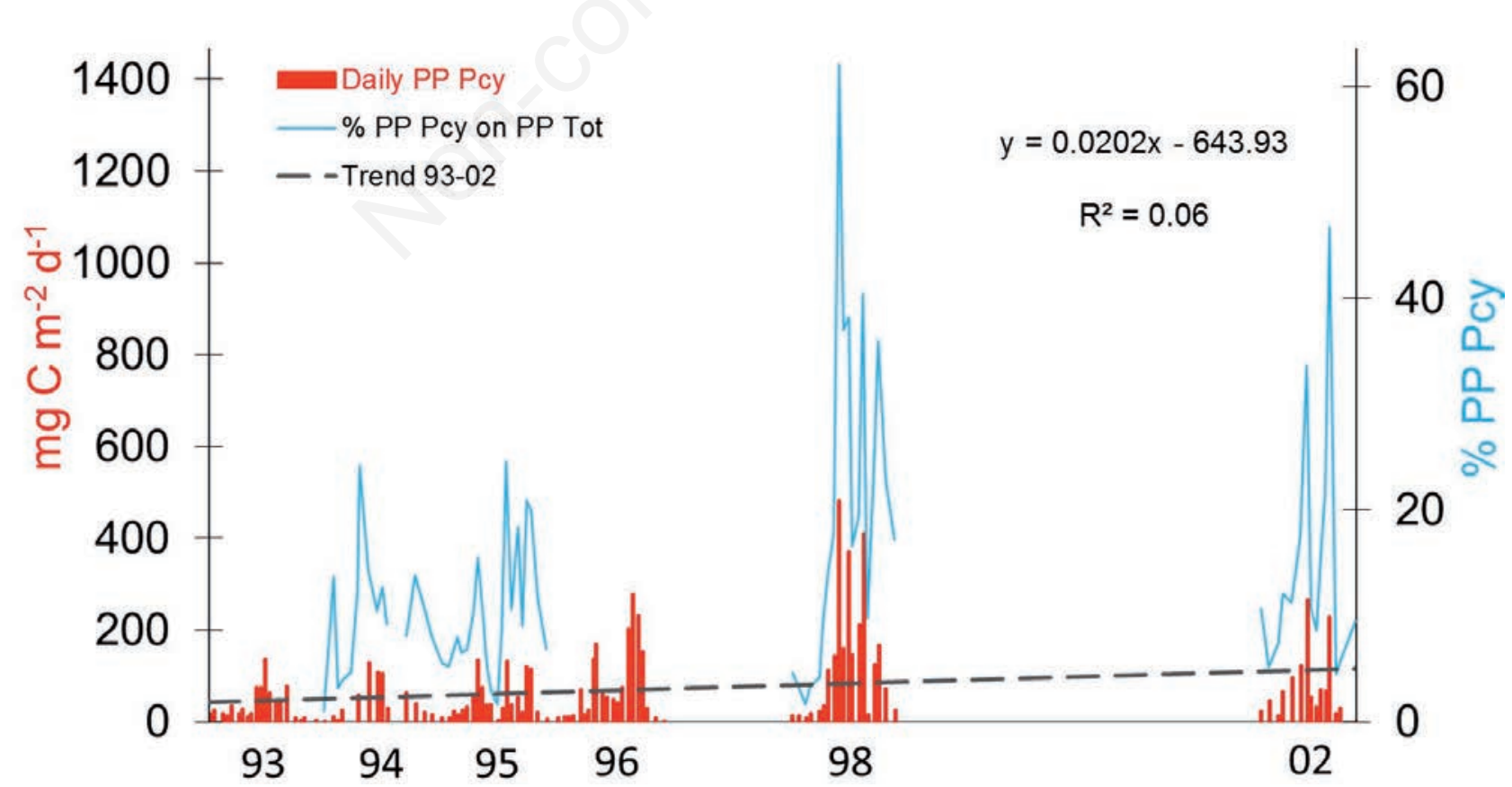

Fig. 4. Picophytoplankton primary production (PP pico: $\mathrm{mg} \mathrm{C} \mathrm{m}^{-2} \mathrm{~d}^{-1}$ ) and percentage on total phytoplankton production in Lake Maggiore. The 1993 and 1996 data were estimated production. The equation of the regression and the $\mathrm{r}^{2}$ value is reported. 
Maggiore (14\% of DAPI signals at $350 \mathrm{~m}$ depth, station Ghiffa), and Thun (14\% of DAPI signals at $120 \mathrm{~m}$ depth).

Cell abundances of Thaumarchaeota and Bacteria calculated from CARD-FISH showed that despite the relative increase of Thaumarchaeota with depth, their abundances were always lower than those of Bacteria (Fig. 12). The highest Thaumarchaeota abundances were found in Lakes Como $\left(188 \times 10^{3}\right.$ cells $\left.\mathrm{mL}^{-1}\right)$ and Thun $\left(175 \times 10^{3}\right.$ cells $\left.\mathrm{mL}^{-1}\right)$. A positive significant correlation between Thaumarchaeota numbers and water depth (normalized data, Pearson product moment correlation, $n=44$, $\mathrm{r}=0.480, \mathrm{P}=0.001$ ), and an inverse significant correlation between abundances of Bacteria and water depth were found (normalized data, Pearson product moment correlation, $\mathrm{n}=44, \mathrm{r}=-0.465, \mathrm{P}=0.0015$ ) (Fig. 13).

Recently, we extended the study to other subalpine lakes and to different seasons (Callieri et al., 2015). Although their percentages and abundances vary along the trophic gradient and with mixing conditions, a general

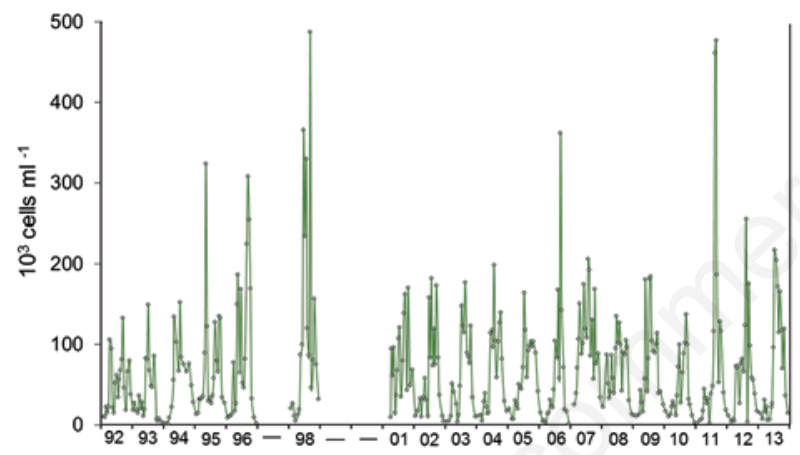

Fig. 5. Long-term picocyanobacteria abundance dynamics in Lake Maggiore, Northern Italy.

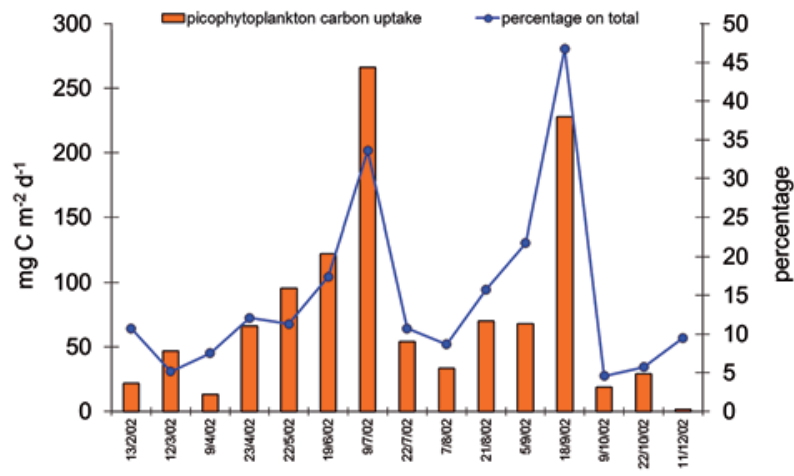

Fig. 6. Picophytoplankton primary production $\left(\mathrm{mg} \mathrm{C} \mathrm{m}^{-2} \mathrm{~d}^{-1}\right)$ and percentage on total phytoplankton production in Lake Maggiore, 2002. pattern common to all the deep lakes was observed. In summer, during stratification, Thaumarchaeota were restricted to the oxygenated hypolimnion. In spring, even at partial water column mixing in oligomictic or meromictic lakes, Thaumarchaeota were also present in the epilimnion. Furthermore, temperature emerged as the main environmental driver of Thaumarchaeota abundance in the deep subalpine lakes. The presence and activity of Thaumarchaeota in the hypolimnion of deep lakes indicates that the mesophilic component of the domain of Archaea needs to be studied not only in the oceans but also in freshwater. Biogeochemical cycles in the deep hypolimnion can have comparable importance with those occurring in the photic zone.

\section{CONCLUSIONS AND NEW PERSPECTIVES}

Picocyanobacteria are an important component of the trophic structure of aquatic ecosystems. They are distrib-

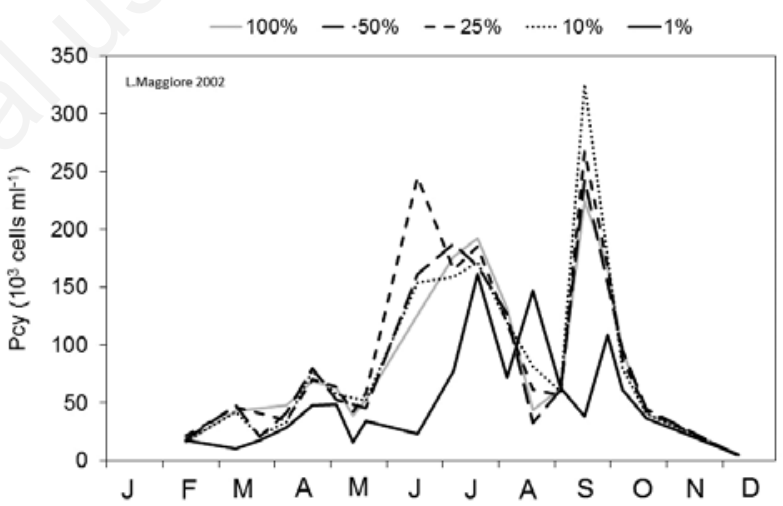

Fig. 7. Picocyanobacteria abundance at different water layer with different irradiance $(100 \%, 50 \%, 25 \%, 10 \%$ and $1 \%$ of surface PAR), in Lake Maggiore, 2002.

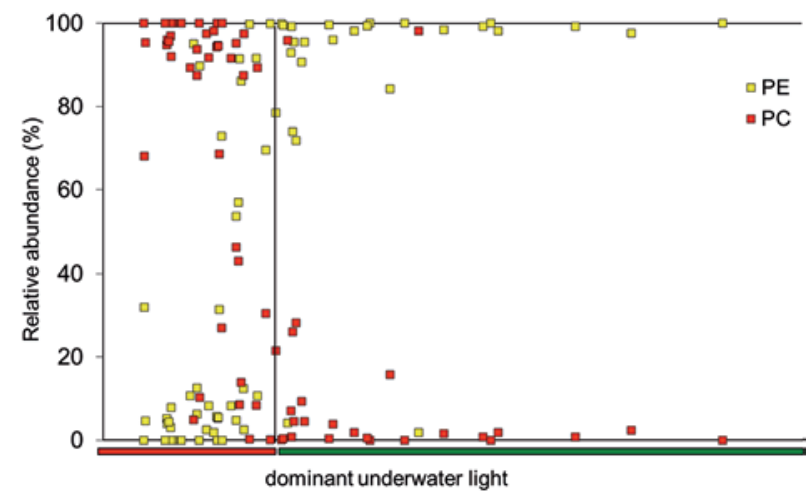

Fig. 8. Phycoerithryn (PE) and phycocyanin (PC) relative abundance in 32 lakes with different water quality. From: Vörös et al., 1998 . 
uted worldwide and are ubiquitous in systems of varying trophic state. Their significance has become clearer only in the last few decades, and this knowledge depended upon an improved understanding of the phylogenetic evolution of Cyanobacteria. It appears that the form-genus Synechococcus likely represents the ancestral morphology from which other types evolved, including colonial forms. We know that there are many clusters of non-marine pic- ocyanobacteria that have been found within the picophytoplankton clade, and that phylogenies revealed a high diversity of Synechococcus strains. The local adaptation of different ecological niches can be related to the highly variable number of horizontally acquired genes, opening new perspectives to the understanding of the adaptation.

Thaumarchaeota numbers were higher in the hypolimnion of lakes than in the epilimnion. In the deep zone

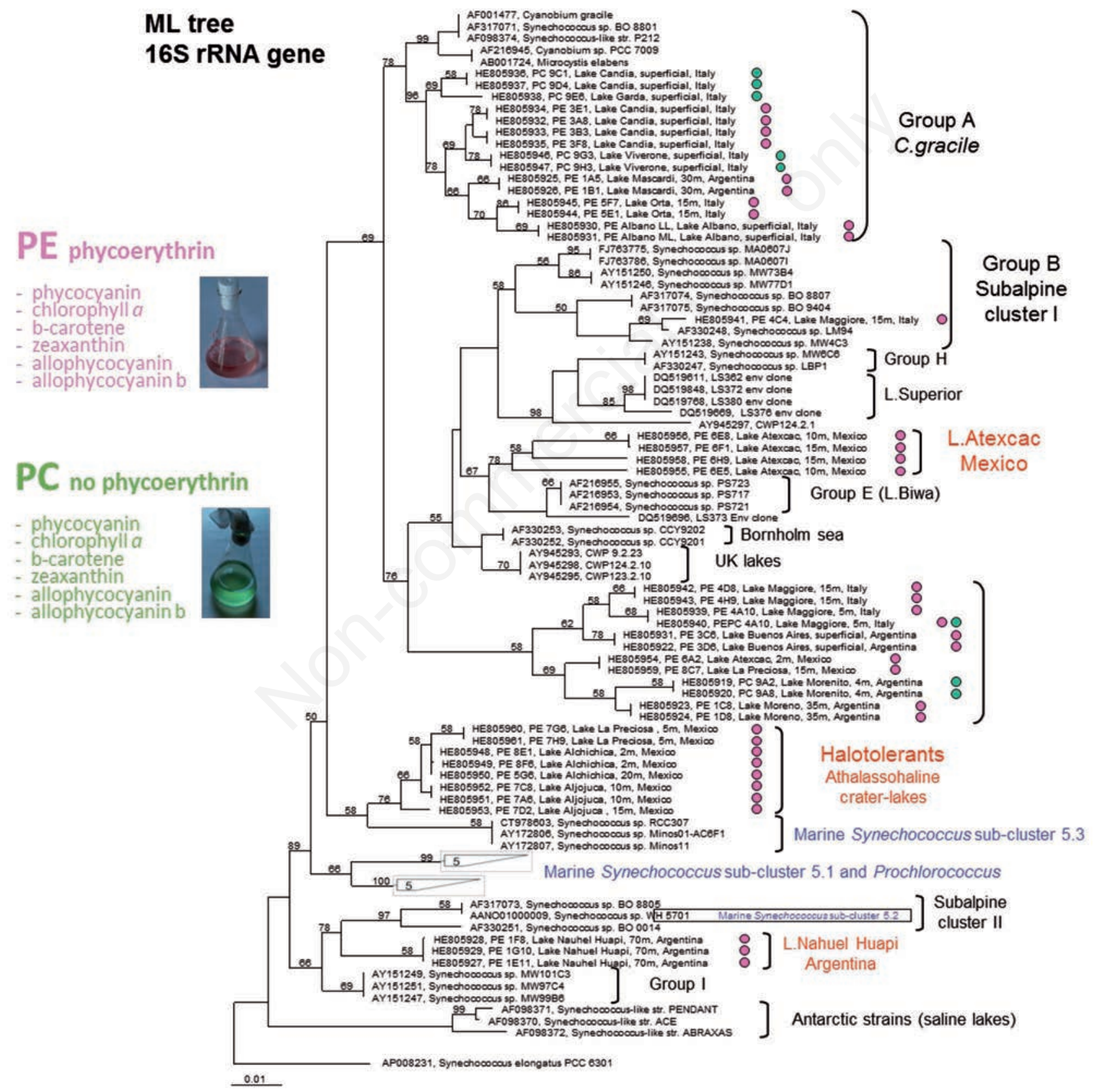

Fig. 9. Maximum-likelihood (ML) tree inferred from 16S rRNA gene sequences of 43 isolated strains from lakes in Italy, Mexico and Argentina. Terminal branches display GenBank accession numbers, name of the strains, of the lakes, depth and location. From: Callieri et al., 2013. 
of the lakes they have the important role of ammonia-oxidizers. We measured in situ the Archaea $\mathrm{CO}_{2}$ uptake in Lake Maggiore. In the hypolimnion of this lake, we recognized that Archaea are responsible for $28 \%$ (52.7 $\pm 0.4 \mu \mathrm{g} \mathrm{C}$ $\mathrm{m}^{-3} \mathrm{~d}^{-1}$ ) of the total dark $\mathrm{CO}_{2}$ uptake. Their activity in the aphotic zone corresponds to $87 \%$ of picophytoplanktonic production taking place in the photic zone. Although deep hypolimnia of freshwater lakes comprised a lower percentage of Thaumarchaeota than bathypelagic marine waters, Thaumarchaeota abundances were higher (around $200 \times 10^{3}$ cells $\mathrm{mL}^{-1}$ ). The studies on Thaumarchaeota indicated that the hypolimnia of deep lakes, often disregarded, are important in microbial metabolisms of carbon and nitrogen cycle, and dark $\mathrm{CO}_{2}$ fixation rates can be comparable to the photosynthetic fixation occurring in photic zones.

Future research on aquatic microbial ecology should be directed towards picocyanobacteria, bacteria and Archaea at a single-cell level, to their association, competition and predation in the aquatic microbial trophic chains. Niche partitioning is the basis of community complexity as it avoids direct competition, enables adaptation to different micro-niches and fosters cooperative interaction among specialised microorganisms. Furthermore, the study at single-cell level, looking individually at relevant uncultured microorganisms, can highlight the large genetic repository of functions existing even within close phylogenetically-related organisms both in freshwater and marine systems.

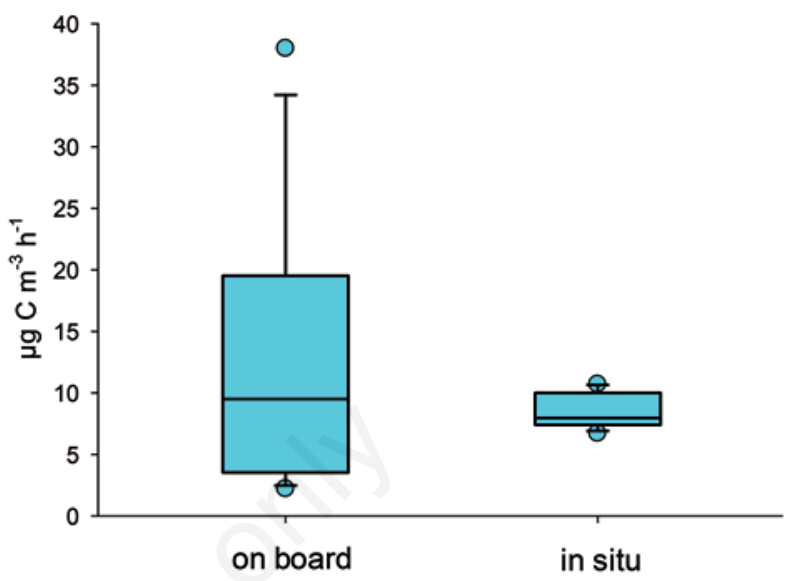

Fig. 10. Mean values and ranges of dark $\mathrm{CO}_{2}$ uptake $\left(\mu \mathrm{gC} \mathrm{\textrm {m } ^ { - 3 }}\right.$ $\mathrm{h}^{-1}$ ) obtained with in situ and on board incubations. Lines within the boxes, boundaries, error bars and dots mark are respectively median, $25^{\text {th }}-75^{\text {th }}$ percentiles, minimum and maximum values, and outliers. Modified from Callieri et al., 2014.

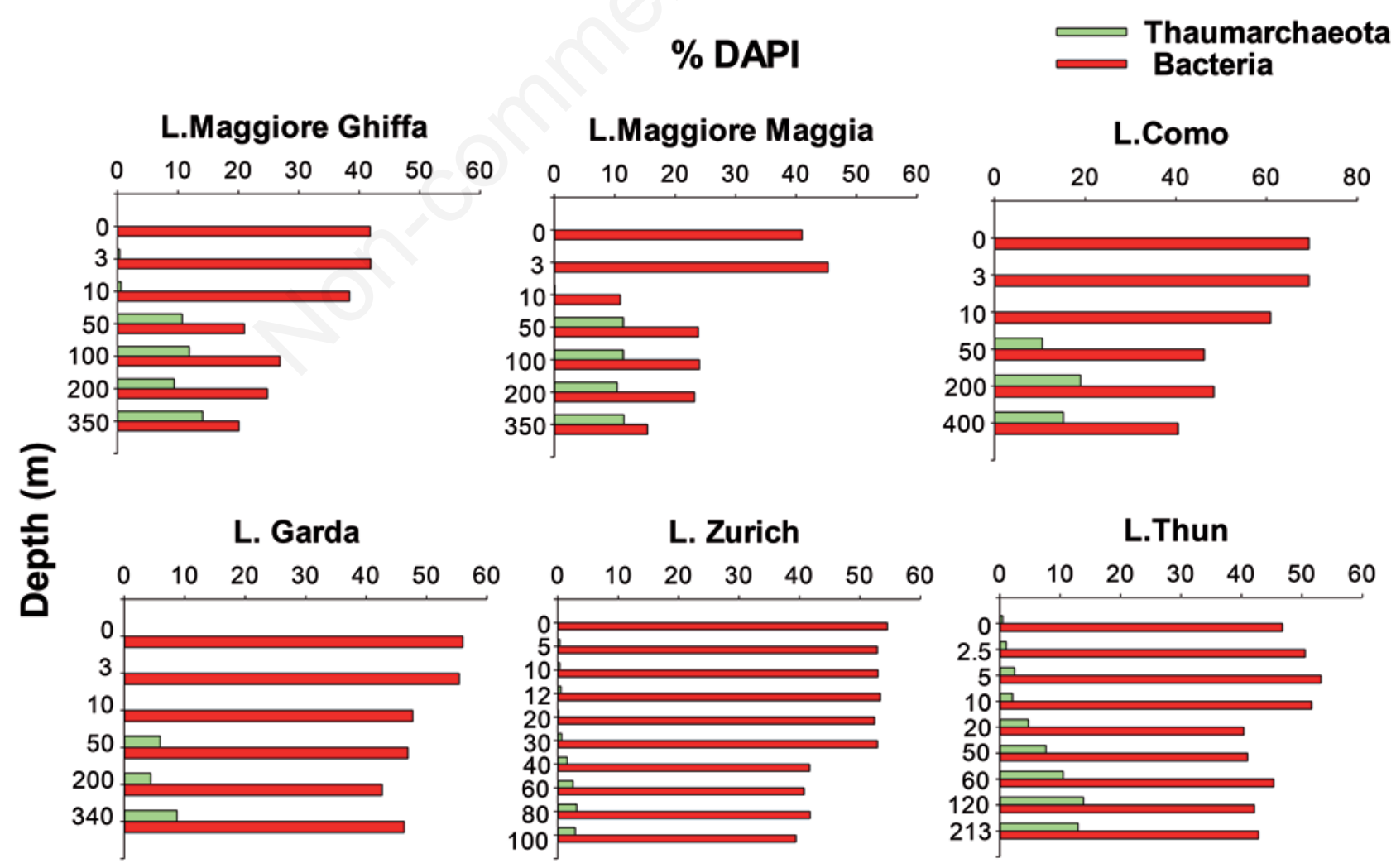

Fig. 11. Percentage of Thaumarchaeota and Bacteria of total DAPI counts in the depth profiles of five subalpine lakes during stratification. Lake Maggiore was sampled in two stations (Ghiffa and Maggia). 


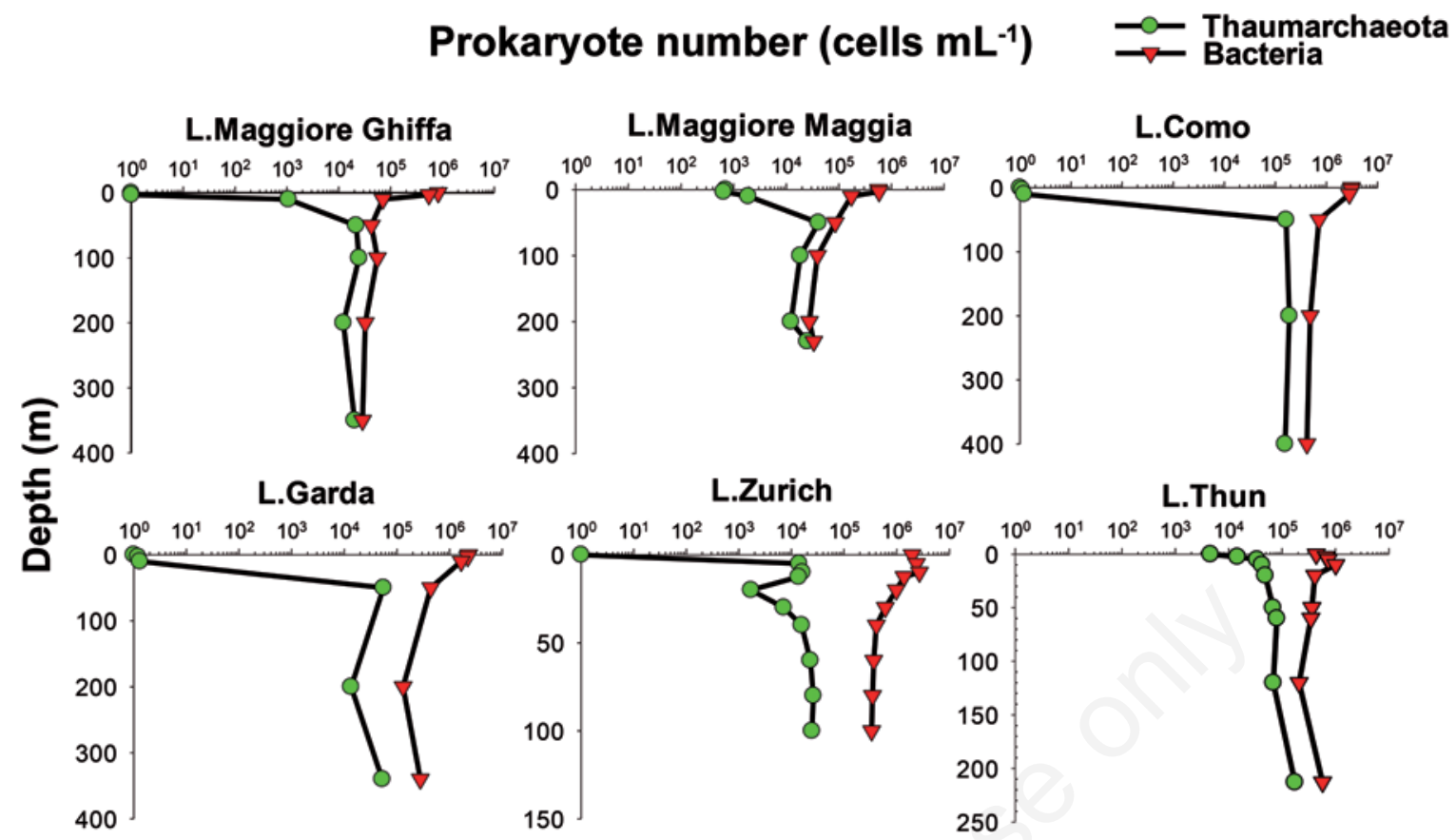

Fig. 12. Total cell number (cells $\mathrm{mL}^{-1}$ ) of Thaumarchaeota (circles) and Bacteria (triangles) in the depth profiles of five subalpine lakes during stratification. Lake Maggiore was sampled in two stations (Ghiffa and Maggia).
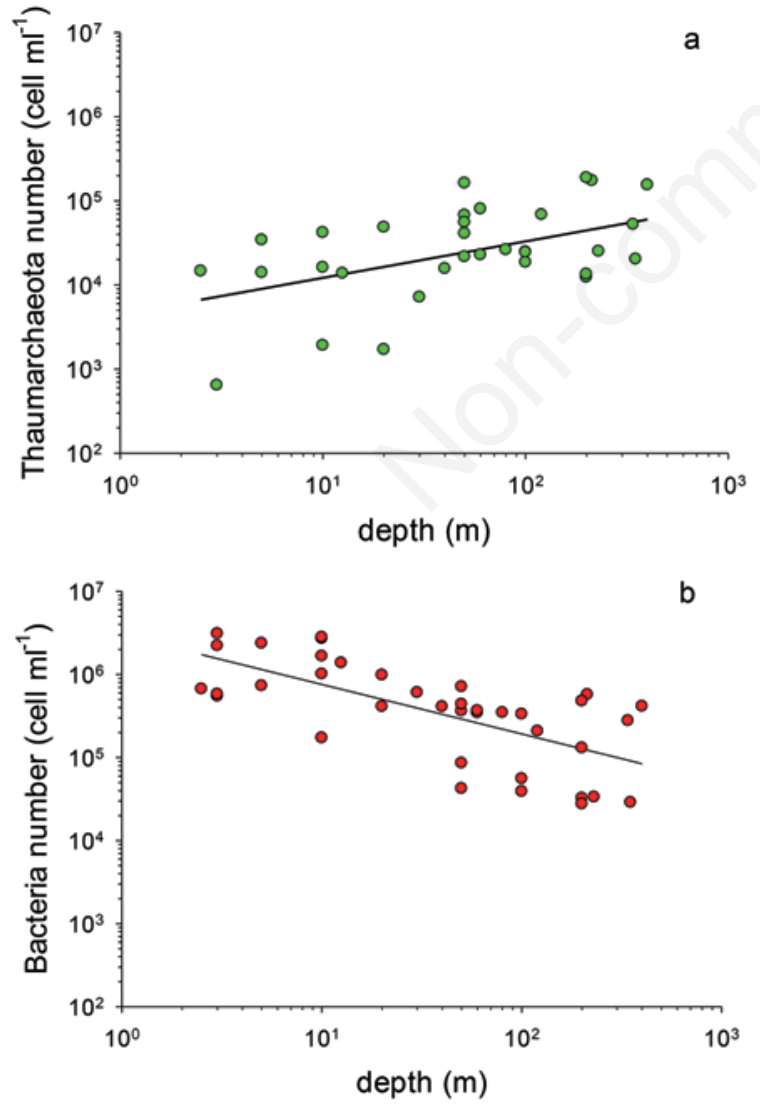

Fig. 13. Log-log relation between the depth and the number of Thaumarchaeota (a) and of Bacteria (b), in five subalpine deep lakes.

\section{ACKNOWLEDGEMENTS}

I want to thank all my co-workers who contributed to my knowledge on picocyanobacteria and Archaea. I am in debt to M. Salcher (University of Zurich, Switzerland) for the countings of Thaumarchaeota of L. Thun and L. Zurich. The research on Lake Maggiore was funded by the International Commission for the Protection of Italian-Swiss Waters (CIPAIS).

\section{REFERENCES}

Auguet JC, Borrego CM, Baneras L, Casamayor E, 2008. Fingerprinting the genetic diversity of the biotin carboxylase gene $(a c c \mathrm{C})$ in aquatic ecosystems as a potential marker for studies of carbon dioxide assimilation in the dark. Environ. Microbiol. 10:2527-2536.

Auguet JC, Triadó-Margarit X, Nomokonova N, Camarero L, Casamayor EO, 2012. Vertical segregation and phylogenetic characterization of ammonia-oxidizing Archaea in a deep oligotrophic lake. ISME J. 6:1786-1797.

Becker S, Fahrbach M, Böger P, Ernst A, 2002. Quantitative tracing, by Taq nuclease assays, of a Synechococcus ecotype in a highly diversified natural population. Appl. Environ. Microbiol. 68:4486-4494.

Berg IA, Kockelkorn D, Buckel W, Fuchs G, 2007. A 3-hydroxypropionate /4-hydroxybutyrate autotrophic carbon dioxide assimilation pathway in archaea. Science 318:1782-1786.

Brochier-Armanet C, Boussau B, Gribaldo S, Forterre P, 2008. Mesophilic crenarchaeota: proposal for a third archaeal phylum, the Thaumarchaeota. Nat. Rev. Microbiol. 6:245-252.

Callieri C, 1996. Extinction coefficient of red, green and blue 
light and its influence on Pcy types in lakes at different trophic levels. Mem. Ist. Ital. Idrobiol. 54:135-142.

Callieri C, 2007. Picophytoplankton in freshwater ecosystems: the importance of small-sized phototrophs. Freshwater Rev. $1: 1-28$

Callieri C, Coci M, Corno G, Macek M, Modenutti B, Balseiro E, Bertoni R, 2013. Phylogenetic diversity of nonmarine picocyanobacteria. FEMS Microbiol. Ecol. 85:293-301.

Callieri C, Coci M, Eckert EM, Salcher MM, Bertoni R, 2014. Archaea and Bacteria in deep lake hypolimnion: in situ dark inorganic carbon uptake. J. Limnol. 73:47-54.

Callieri C, Corno G, Caravati E, Rasconi S, Contesini M, Bertoni R, 2009. Bacteria, Archaea and Crenarchaeota in the epilimnion and hypolimnion of a deep holo-oligomictic lake. Appl. Environ. Microbiol. 75:7298-7300.

Callieri C, Cronberg G, Stockner J, 2012. Freshwater picocyanobacteria: single cells, microcolonies and colonial forms, p. 229-271. In: B. Whitton (ed.), Ecology of cyanobacteria II: their diversity in time and space. Springer.

Callieri C, Hernandez-Haviles S, Salcher M, Fontaneto D, Bertoni R, 2015. Distribution patterns and environmental correlates of Thaumarchaeota abundance in six deep subalpine lakes. Aquat. Sci. DOI 10.1007/s00027-015-0418-3.

Callieri C, Lami A, Bertoni R, 2011. Microcolony formation by single-cell Synechococcus strains as a fast response to UV radiation. Appl. Env. Microbiol. 77:7533-7540.

Callieri C, Modenutti B, Queimaliños C, Bertoni R, Balseiro E, 2007. Production and biomass of picophytoplankton and larger autotrophs in Andean ultraoligotrophic lakes: differences in light harvesting efficiency in deep layers. Aquat. Ecol. 80:345-362.

Callieri C, Piscia R, 2002. Photosynthetic efficiency and seasonality of autotrophic picoplankton in Lago Maggiore after its recovery. Freshwater Biol. 47:941-956.

Crosbie ND, Pöckl M, Weisse T, 2003a. Dispersal and phylogenetic diversity of nonmarine picocyanobacteria, inferred from 16S rRNA gene and $c p c \mathrm{BA}$-intergenic spacer sequence analyses. Appl. Environ. Microb. 69:5716-5721.

Crosbie ND, Teubner K, Weisse T, 2003b. Flow-cytometric mapping provides novel insights into the seasonal and vertical distributions of freshwater autotrophic picoplankton. Aquat. Microb. Ecol. 33:53-66.

De Corte D, Yokokawa T, Varela MM, Agogué H, Herndl GJ, 2009. Spatial distribution of Bacteria and Archaea and amoA gene copy numbers throughout the water column of the Eastern Mediterranean Sea. ISME J 3:147-158.

Ernst A, Postius C, Böger P, 1996. Glycosylated surface proteins reflect genetic diversity among Synechococcus spp. of Lake Constance. Arch. Hydrobiol. 48:1-6.

Everroad RC, Wood AM, 2012. Phycoerythrin evolution and diversification of spectral phenotype in marine Synechococcus and related picocyanobacteria. Mol. Phyl. Evol. 64:381-392.

Glover HE, Phinney DA, Yentsch CS, 1985. Photosynthetic characteristics of picoplankton compared with those of larger phytoplankton populations in various water masses in the Gulf of Maine. Biol. Oceanogr. 3:223-248.

Haverkamp THA, Schouten D, Doeleman M, Wollenzien U, Huisman J, Stal LJ, 2009. Colorful microdiversity of Synechococcus strains (picocyanobacteria) isolated from the Baltic Sea. ISME J 3:397-408.
Herndl GJ, Reinthaler T, Teira E, Van Aken H, Veth C, Pernthaler A, Pernthaler J, 2005. Contribution of Archaea to total prokaryotic production in the deep Atlantic Ocean. Appl. Environ. Microbiol. 71:2303-2309.

Hoiczyk E, Hansel A, 2000. Cyanobacterial cell walls: news from an unusual prokaryotic envelope. J. Bacteriol. 182:1191-1199.

Ivanikova NV, Popels LC, McKay RML, Bullerjahn GS, 2007. Lake Superior supports novel clusters of cyanobacterial picoplankton. Appl. Environ. Microbiol. 73:4055-4065.

Jasser I, Arvola L, 2003. Potential effects of abiotic factors on the abundance of autotrophic picoplankton in four boreal lakes. J. Plankton Res. 25:873-883.

Jezberová J, Komárková J, 2007. Morphological transformation in a freshwater Cyanobium sp. induced by grazers. Environ. Microbiol. 9:1858-1862.

Keough BP, Schmidt TM, Hicks RE, 2003. Archeal nucleic acids in picoplankton from Great Lakes on three continents. Microb. Ecol. 46:238-248.

Koblížek M, Komenda J, Masojídek J, Pechar L, 2000. Cell aggregation of the cyanobacterium Synechococcus elongatus: role of the electron transport chain. J. Phycol. 36:662-668.

Komárková J, 2002. Cyanobacterial picoplankton and its colonial formations in two eutrophic canyon reservoirs (Czech Republic). Arch. Hydrobiol. 154:605-623.

Könneke M, Bernhard AE, de la Torre JR, Walker CB, Waterbury JB, Stahl DA, 2005. Isolation of an autotrophic ammonia-oxidizing marine archaeon. Nature 437:543-546.

McMurter HJG, Pick FR, Kelley DE, 1994. Fluorescent characteristics of natural assemblage of fresh water picocyanobacteria. J. Plankton Res. 16:911-925.

Modenutti BE, Balseiro EG, Callieri C, Queimaliños C, Bertoni $\mathrm{R}, 2004$. Increase in photosynthetic efficiency as a strategy of planktonic organisms exploiting deep lake layers. Freshwater Biol. 49:160-169.

Mózes A, Présing M, Vörös L, 2006. Seasonal dynamics of picocyanobacteria and picoeukaryotes in a large shallow lake (Lake Balaton, Hungary). Int. Rev. Ges Hydrobiol. 91:38-50.

Nagata T, Takai K, Kawanobe K, Kim D, Nakazato R, Guselnikova N, Bondarenko N, Mologawaya O, Kostrnova T, Drucker V, Satoh Y, Watanabe Y, 1994. Autotrophic picoplankton in southern Lake Baikal: abundance growth and grazing mortality during summer. J. Plankton Res. 16:945-959.

Passoni S, Callieri C, 2000. Picocyanobacteria single forms, aggregates and microcolonies: survival strategy or species succession? Ver. Int. Verein. Limnol. 27:1879-1883.

Pester M, Christa S, Wagner M, 2011. The Thaumarchaeota: an emerging view of their phylogeny and ecophysiology. Curr. Opin. Microbiol. 14:300-306.

Pick FR, 1991. The abundance and composition of freshwater picocyanobacteria in relation to light penetration. Limnol. Oceanogr. 36:1457-1462.

Scanlan DJ, Ostrowski M, Mazard S, Dufresne A, Garczarek L, Hess WR, Post AF, Hagemann M, Paulsen I, Partensky R, 2009. Ecological genomics of marine picocyanobacteria. Microbiol. Mol. Biol. Rev. 73:249-299.

Stockner J, Callieri C, Cronberg G, 2000. Picoplankton and other non-bloom forming cyanobacteria in lakes, p. 195-238. In: B.A. Whitton and M. Potts (eds.), The ecology of cyanobacteria. Their diversity in time and space. Kluwer Academic. 
Stockner JG, Shortreed KS, 1991. Phototrophic picoplankton: community composition abundance and distribution across a gradient of oligotrophic British Columbia and Yukon Territory lakes. Int. Rev. Ges. Hydrobiol. 76:581-601.

Stockner JG, Shortreed KS, 1994. Autotrophic picoplankton community dynamics in a pre-alpine lake in British Columbia, Canada. Hydrobiologia 274:133-142.

Urbach E, Vergin KL, Young L, Morse A, Larson GL, Giovannoni SJ, 2001. Unusual bacterioplankton community structure in ultra-oligotrophic Crater Lake. Limnol. Oceanogr. 46:557-572.

Vörös L, Callieri C, Balogh KV, Bertoni R, 1998. Freshwater picocyanobacteria along trophic gradient and light quality range. Hydrobiologia 369/370:117-125.

Yakimov MM, La Cono V, Smedile F, DeLuca TH, Juárez S, Ciordia S, Fernández M, Albar JP, Ferrer M, Golyshin PN, Giuliano L, 2011. Contribution of crenarchaeal autotrophic ammonia oxidizers to the dark primary production in Tyrrhenian deep waters (Central Mediterranean Sea). ISME J. 5:945-961.

Yokokawa T, Sintes E, De Corte D, Olbrich K, Herndl G, 2012. Differentiation of leucine incorporation of Archaea and Bacteria throughout the water column of the eastern atlantic using metabolic inhibitors. Aquat. Microb. Ecol. 66:247-256. 